\title{
The expression of p53 and hsp70 proteins after treatment with Annona muricata Linn leaf for activating apoptotic and lead to homeostasis program of Raji cells
}

\author{
Okid Parama Astirin ${ }^{1}$, Adi Prayitno ${ }^{2}$, Anif Nur Artanti ${ }^{3}$, Meutia Srikandi Fitria ${ }^{1}$, \\ Dyah Ayu Witianingsih ${ }^{1}$, Dwimei Ayudewandari Pranatami ${ }^{1}$, Suhartono Taat Putra 4 \\ ${ }^{1}$ Department of Biology, Mathematic and Natural Science Faculty, Sebelas Maret University, Surakarta, Indonesia. \\ ${ }^{2}$ Department of Pathobiology, Medical Faculty, Sebelas Maret University, Surakarta, Indonesia. \\ ${ }^{3}$ Department of Pharmacy, Mathematic and Natural Science Faculty, Sebelas Maret University, Surakarta, Indonesia. \\ ${ }^{4}$ Department of Pathobiology, Medical Faculty, Airlangga University, Surabaya, Indonesia.
}

Received December 24, 2013; Revised March 08, 2014; Accepted March 30, 2014; Published Online April 09, 2014

\section{Technical Report}

\begin{abstract}
Purpose: Organic extracts of plant Annonaceae enhances apoptosis in animal cells and get the drives to reach a new homeostasis. The incidence rate of nasopharyngeal cancer in Indonesia is quite high. Protein 53Kd (p53) play a role in apoptosis process, being heat shock protein 70 (hsp70) play a role in homeostasis. The aim of this research is to identify the apoptotic effects of Annona muricata Linn leaf toward Raji cells by observing the p53 and hsp70 expression. Methods: Apoptotic assay was performed in 24 wells micro-culture plate. Raji cells were prepared as $2 \times 10^{4}$ cells in $100 \mathrm{ml}$ RPMI media per well. Roswell Park Memorial Institute (RPMI) medium was created and solvent was controlled with Dimethyl Sulfoxide (DMSO) solvent 0.25. Apoptotic test was performed by calculating trypan-blue-dye exclution. The cells were then grown in micro-culture plate with media plus extract non-lethal concentration of partition and fractionation of Annona muricata Linn leaf. The sampling was performed for 24 hours. The number of living cells was calculated in each of these well and incubation time were determined. Immunohistochemical staining was done to identify the expression of p53 and hsp70. Results: The results showed that Raji cells treated with partition of Annona muricata Linn leaf in ethyl acetate solvent $133.00 \%$ resulted in higher apoptosis. Another results showed that Raji cells treated with fractionation Annona muricata Linn leaf in ethyl acetate solvent $103.20 \%$ resulted in higher apoptosis. The expression of p53 after treatment with fractionation Annona muricata Linn leaf was higher than before while hsp70 expression after treatment with fractionation Annona muricata Linn leaf was lower. Conclusion: The conclusion is the higher the dose of Annona muricata Linn the higher the p53 expression thereby activates apoptosis process The higher dose of Anonna muricata Linn also leads to lower hsp70 expression indicating stable homeostasis of Raji cells.
\end{abstract}

Keywords: Annona Muricata Linn Leaf; p53; hsp70; Apoptosis; Homeostasis; Raji Cell

\section{Introduction}

Drug substance from herbs interacted with virus in the development of cancer do not so by interacting by the agent but rather through a direct effect on cell transformed apoptosis and proliferation. Although the interaction between virus and herbs medicines is plausible larger more biological

*Corresponding author: Adi Prayitno; Department of Pathobiology, Medical Faculty, Sebelas Maret University, Surakarta, Indonesia.

Cite this article as:

Astirin OP, Prayitno A, Artanti AN, Fitria MS, Witianingsih DA, Pranatami DA, Putra ST. The expression of p53 and hsp70 proteins after treatment with Annona muricata Linn leaf for activating apoptotic and lead to homeostasis program of Raji cells. Int J Cancer Ther Oncol 2014; 2(2):02028. DOI: 10.14319/ijcto.0202.8 details studies need conducted to validate this preliminary finding. ${ }^{1}$ Annona muricata Linn has been shown to have strong anticancer effect on cancer cells of reporting via apoptosis. However the fundamental mechanism are still unclear. ${ }^{2}$ So molecular targeting for the cancer therapy including inactivating virus gene product has been developing and on the way to clinical use. ${ }^{3}$ Considering the high potential herbs in managing various disease, need to be researched the Annona muricata Linn, especially in kill nasopharyngeal cancer cells.

Nasopharyngeal carcinoma (NPC) is rare malignancy with an incidence under 1 per 100,000 person-year. The distribution 
of NPC suggest that both environmental and genetic traits factors contribute to its development. ${ }^{4}$ This carcinoma has complex aetiology. ${ }^{5}$ Nasopharyngeal carcinoma has remarkable epidemiological features including racial and familial aggregations. ${ }^{6}$ Prevalence was nearly $60 \%$ of malignant head and neck cancer. Cancer begin with a scene gene expression imbalance in apoptosis and cell proliferation, and DNA repair. ${ }^{7,8}$ Epstein Barr virus infection in early age combined with frequent exposure to carcinogenic co-factor is suggested to cause the NPC development. Higher LMP-1 EBV expression was related to more loco regional progressivity. ${ }^{9}$ Given the high number of pain due to nasopharyngeal cancer we need to be controlled in order to keep the quality of human resources.

The role of Annona muricata Linn extract, expression of p53 and hsp70 proteins may be explained with path biological examination. ${ }^{10,11}$ Concept above may provide explanation on the decrease of NPC.

Aetiology of NPC is complex involving genetic susceptibility factor including EBV infection and exposure to chemical carcinogens. Development of the disease is started by a viral infection and continue to change in gene level then occurring change in epigenetic disrupt significantly. ${ }^{12}$ Molecular description of NPC are the anti-apoptotic bcl2 is over-expressed and latent membrane protein-1 (Lmp-1) EBV is detected so the last a decline in the expression of p53 significantly. ${ }^{13}$ Other studies demonstrate that p53 induce apoptosis is important in cell death after enjury. ${ }^{14}$ Heat shock protein 70 also suspected of facilitating a groove apoptosis. ${ }^{15}$ As known protein heat shock in a continuous manner and thorough expressed on majority of normal tissue and cancer. ${ }^{16}$ An increase of expression hsp70 responsible on protein folding impact on function that lead and play a role in sick pathogenesis. ${ }^{17,18,19} \mathrm{All}$, it is hope that groove scene carcinoma of the nasopharynx can be controlled using extract leaves Annona muricata Linn with an increase occurrence of an expression of p53 so that mediated apoptosis viable and the decline of expression hsp70 so that homeostasis cells can be achieved.

\section{Methods and Materials}

The first stage was to develop the Raji cells culture using Fresney method with many modifications. ${ }^{20}$ Apoptotic assay was performed on 24 well micro-culture plate. Raji cells were prepare as $2 \times 10^{4}$ cells in $100 \mathrm{ml}$ Roswell Park Memorial Institute (RPMI) Media. This was followed by the creation of RPMI control and solvent plus Dimethyl Sulfoxide (DMSO) $0.25 \%$.

Subsequently a precipitate during $24 \mathrm{hr}$ in culture medium than the Raji cell were grown in microplate with media plus extract with a non lethal concentration of partition and fractionation Annona muricata Linn leaf. Of sampling was peformed for 24hrs. Apoptotic test was performed by calculating tryphan blue dye exclution. The number of living cells were calculate in each of these wells and incubation time were determined. ${ }^{2,21}$

Immunohistochemical stainings was done with TSA-indirect method (Nen life science product, Renaissence) using monoclonal antibody against p53 (1:500) produce by Dako and hsp70 (1:500) was produced by Stressgen. Photo microscopic was collected using aX100 objective lens (Nikkon). ${ }^{22}$

\section{Results}

The first result showed (Figure $1 \mathrm{~A}$ and $\mathrm{B}$ as well as Table 1) that Raji cell are treated with partition of Annona muricata Linn leaf in ethyl acetate the apoptotic rate was higher (2000 $\mu \mathrm{g} / \mathrm{ml}$ had $133.00 \% ; 15.625 \mu \mathrm{g} / \mathrm{ml}$ had $0.00 \%)$ and in ethanol destilate water the apoptotic rate was lower (2000 $\mu \mathrm{g} / \mathrm{ml}$ had $42.50 \% ; 15.625 \mu \mathrm{g} / \mathrm{ml}$ had $0.05 \%$ )

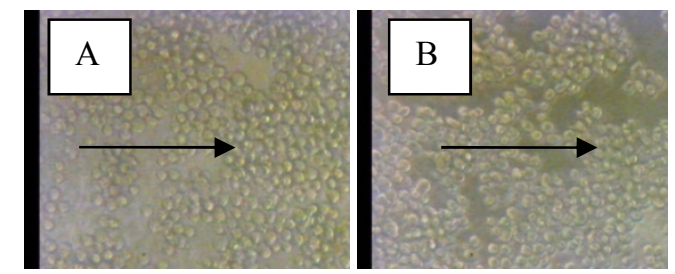

FIG. 1: Raji cells are treated with partition of leaves Annona muricata Linn. Left: (A) Before treatment and, Right: (B) After treatment.

Another results showed (Figure $2 \mathrm{~A}$ and B and Table 2) that Raji cells are treated with fractionation of Annona muricata Linn leaf in n-hexan the apoptotic rate was higher (2000 $\mu \mathrm{g} / \mathrm{ml}$ have $103.20 \% ; 15.625 \mu \mathrm{g} / \mathrm{ml}$ had $7.17 \%$ ) and in ethanol distillate water the apoptotic rate was lower (2000 $\mu \mathrm{g} / \mathrm{ml}$ had $40.24 \% ; 15.625 \mu \mathrm{g} / \mathrm{ml}$ had $6.06 \%$ ).

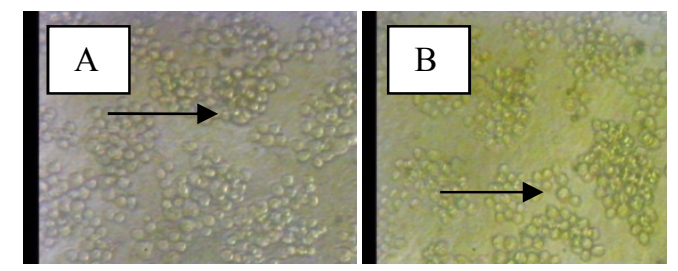

FIG. 2: Raji cells are treated with fractionation of leaves Annona muricata Linn. Left: (A) Before treatment and, Right. (B) After treatment.

The third results in Figure 2 showed that Raji cells are treated with fractionation of Annona muricata Linn leaf so the p53 expression before treatment was lower while the expression after treatment was higher. The results in Table 3 showed that Raji cells are treated with fractionation of Annona muricata Linn leaf in ethyl acetate the p53 strong expression was higher $(55 \%)$ and in $\mathrm{n}-\mathrm{Hexan}$ the $\mathrm{p} 53$ strong expression was lower (51\%). 
The third results in Figure 3 showed that Raji cells are treated with fractionation of Annona muricata Linn leaf so the hsp70 expression before treatment was higher while the expression after treatment was lower.
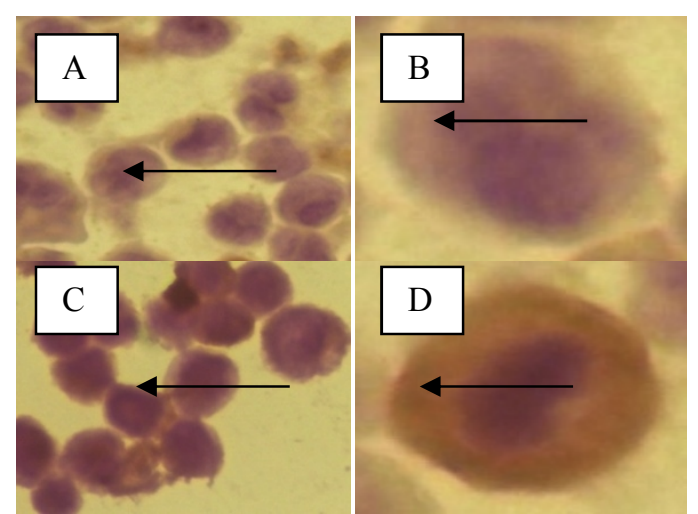

FIG. 2: Raji cells are treated with fractionation of leaf Annona muricata Linn so the p53 expression (bluish) before treatment was lower (A: X100 and B: X400) while the expression (brownish) after treatment was higher (C: X100 and D: X400)
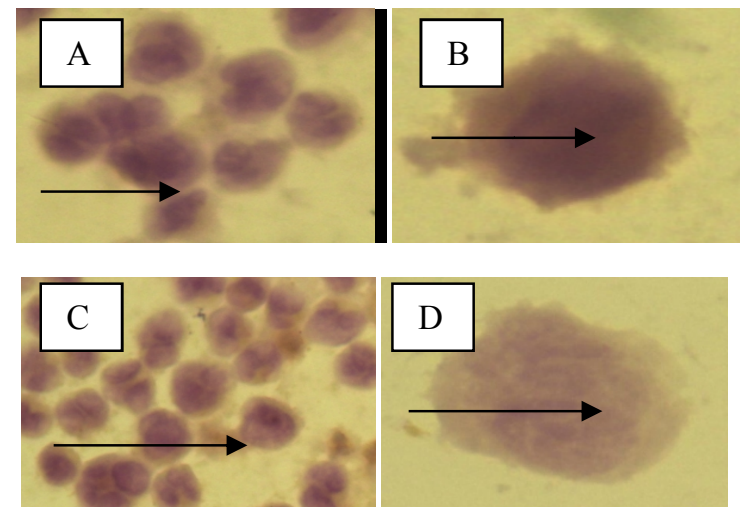

FIG. 3: Raji cells are treated with fractionation of leaves Annona muricata Linn so the hsp70 expression (brownish) before treatment was higher (A: X100 and B: X400) while the expression (bluish) after treatment was lower (C: X100 and D: X400).

The results in Table 4 showed that Raji cells are treated with fractionation of Annona muricata Linn leaf in ethyl acetate the hsp70 strong expression was higher (57 \%) and in ethanol water the hsp70 strong expression was lower (44\%).

TABLE 1: Raji cells are treated with partition of leaf Annona muricata Linn in ethyl acetate the apoptotic rate was higher (2000 $\mu \mathrm{g} / \mathrm{ml}$ had 133.00 $\% ; 15.625 \mu \mathrm{g} / \mathrm{ml}$ had $0.00 \%$ ) and in ethanol distillate water the apoptotic rate was lower $(2000 \mu \mathrm{g} / \mathrm{ml} \mathrm{had} 42.50 \% ; 15.625 \mu \mathrm{g} / \mathrm{ml} \mathrm{had} \mathrm{0,05 \% ).}$

\begin{tabular}{llcccc}
\hline \hline \multirow{2}{*}{ No. } & Concentration & \multicolumn{4}{c}{ Cell Death Rate (\%) In Solvent } \\
\cline { 3 - 6 } & & Ethyl Acetate & n-Hexan & Chloroform & Ethanol Water \\
\cline { 3 - 6 } 1 & $2000.000 \mu \mathrm{g} / \mathrm{ml}$ & 133.00 & 103.20 & 81,92 & 42,50 \\
\hline 2 & $15,625 \mu \mathrm{g} / \mathrm{ml}$ & 0.00 & 7.17 & 9,27 & 0,05 \\
\hline \hline
\end{tabular}

TABLE 2: Raji cells are treated with fractionation of leaves Annona muricata Linn in n-hexan the apoptotic rate was higher $(2000 \mu \mathrm{g} / \mathrm{ml}$ have $103.20 \% ; 15.625 \mu \mathrm{g} / \mathrm{ml}$ had $7.17 \%)$ and in ethanol distillate water the apoptotic rate was lower $(2000 \mu \mathrm{g} / \mathrm{ml} \mathrm{had} 40.24 \% ; 15.625 \mu \mathrm{g} / \mathrm{ml}$ had $6.06 \%)$.

\begin{tabular}{|c|c|c|c|c|c|}
\hline \multirow[t]{2}{*}{ No. } & \multirow[t]{2}{*}{ Concentration } & \multicolumn{4}{|c|}{ Cell Death Rate (\%) In Solvent } \\
\hline & & n-Hexan & Chloroform & Ethyl Acetate & Ethanol Water \\
\hline 1 & $2000.000 \mu \mathrm{g} / \mathrm{ml}$ & 103.20 & 92.37 & 87,55 & 40,24 \\
\hline 2 & $15,625 \mu \mathrm{g} / \mathrm{ml}$ & 7.17 & 9.27 & 25,48 & 6.06 \\
\hline
\end{tabular}

TABLE 3: Immunohistochemistry staining using p53 antibody anti p53 protein in Raji cells that are treated with the active compounds of fractionation Annona muricata Linn leaf. The expression of p53 was $55 \%$ strong in ethyl acetate solvent and $38 \%$ strong in n-Hexan solvent.

\begin{tabular}{|c|c|c|c|c|c|}
\hline \multirow[t]{2}{*}{ No } & \multirow[t]{2}{*}{ In Solvent } & \multicolumn{3}{|c|}{ p53 } & \multirow[b]{2}{*}{ Total } \\
\hline & & Tenuous & Midts & Strong & \\
\hline 1 & Ethyl Acetate & $8(09 \%)$ & $31(36 \%)$ & $47(55 \%)$ & $86(100 \%)$ \\
\hline 2 & Chloroform & $7(12 \%)$ & $19(33 \%)$ & $31(55 \%)$ & $57(100 \%)$ \\
\hline 3 & Ethanol Water & $9(20 \%)$ & $11(25 \%)$ & $24(55 \%)$ & $44(100 \%)$ \\
\hline 4 & n- Hexane & $15(19 \%)$ & $23(30 \%)$ & $38(51 \%)$ & $76(100 \%)$ \\
\hline & Mean & $(15 \%)$ & $(31 \%)$ & $(54 \%)$ & \\
\hline
\end{tabular}

TABLE 4: Immunohistochemistry staining using hsp70 antibody anti hsp70 protein in Raji cells that are treated with the active compounds of fractionation Annom muricata Linn leaf. The expression of hsp70 was 57\% strong in ethyl acetate solvent and $44 \%$ strong in ethanol water solvent.

\begin{tabular}{|c|c|c|c|c|c|}
\hline \multirow[t]{2}{*}{ No } & \multirow{2}{*}{ In Solvent } & \multicolumn{3}{|c|}{ Hsp70 } & \multirow[b]{2}{*}{ Total } \\
\hline & & Tenuous & Midts & Strong & \\
\hline 1 & Ethyl Acetate & $5(15 \%)$ & $9(27 \%)$ & $19(57 \%)$ & $33(100 \%)$ \\
\hline 2 & Chloroform & $11(16 \%)$ & $18(27 \%)$ & $37(56 \%)$ & $66(100 \%)$ \\
\hline 3 & n-Hexane & $7(15 \%)$ & $14(31 \%)$ & $23(52 \%)$ & $44(100 \%)$ \\
\hline \multirow[t]{2}{*}{4} & Ethanol water & $20(21 \%)$ & $31(33 \%)$ & $41(44 \%)$ & $92(100 \%)$ \\
\hline & Mean & $(18 \%)$ & $(30 \%)$ & $(52 \%)$ & \\
\hline
\end{tabular}




\section{Discussion}

The usual approach to cancer prevention are by: prevention of interaction with cancer causing agent, increasing defense mechanism againt cancer and lifestyle modification. ${ }^{23,}{ }^{24} \mathrm{~A}$ number of herb have been found to inhibit proliferation, supress angiogenesis, retard metastases and enhence chemotherapy, induce apoptosis both in vitro and in vivo. ${ }^{25}$, 26 Those studies have shown the possibility of compounds that selectivity kill cancer cells without damaging normal cells. The compound was derived from Pandanus conoideus Lam that tested for cancer therapy. The study above was canducted at the level of cellular. ${ }^{2}, 4,27$ Currenly the treatment of cancer focused on how to enhance apoptosis considering has been proven that occur immortalization on cancer. ${ }^{28}$ The refugees of apoptosis can occur through multiple pathway. One point that has a close link with cancer through the induction apoptosis is much play by p53 proteins. $^{29}$

The expression of p53 protein is a form of cell respone to a stressor. ${ }^{29}$ Decrease expression of the $\mathrm{p} 53$ protein can cause a decrease in cell apoptosis mechanism. A protein p53 are known as a cancer inhibitor and proteins that plays an important role in apoptosis regulation. A hallmark of cancer is a decline in apoptosis and increase proliferation of the cells. Fivety five of human cancer lose in p53 function of due to gene mutations and proteins misfolding and finally causes degradation of ubiquitine chaperones. ${ }^{30,31,32,33}$ The recovery of p53 function could potentially trigger a mass apoptosis that effectively kill cancer cells

To turn stress gene it is essential in order to respond to stress. Stress (either physical or chemical) also activate or pressing many gene, including the various housekeeping gene. A proteins stress, who temp by stress gene, is critical role in biogenesis physiological proteins. ${ }^{34}$ Heat shock proteins continously and thoroughly expressed in the most normal tissue and cancer. ${ }^{16}$ and implication for the interaction of many protein folding, such as united states translocation and prevent improper aggregation and degradation. Increased expression of hsp70 responsible for the misfolding of proteins implicated in the fascicle that lead and constribute to the pathogenesis of pain including cancer incidence. ${ }^{17,18,19}$ Molecules chaperone e.g. hsp70 also play a role in groves the target protein that active in mitochondria, in this the protein folding for the benefit of the activity at mitochondria. Chaperone mitichondria a protein heat shock 70 to faciliting transport protein that goes through membrane mitochondria and do folding in a matrix. The reaction is conducted by two complex mhsp70 different: 1 . The form of wich is the form of mHsp70-ADP Bound complex wich are at the inner membrane mitochondria and complex import consisted of $\mathrm{mHsp70}$, a fastener tim44 in its membrane and $\mathrm{mHsp20}-30 .{ }^{35}$ 2. The form of ATP-bound of $\mathrm{mHsp70}$ is the form of complex who was insite the matrix mitochondria and folding complex consisted of $\mathrm{mHsp70}, \mathrm{mHsp} 40$ homologue (mdj1), and mHsp20-30.35, 36, 37

Acetogenin in the Annonaceae is composed of mono-unsaturated acids. As anticancer acetogenin can serve as immunosupressive, pesticide, antiprotozoal and antimicrobial. Acetogenin inhibit mitochondrial to produce ATP, resulting in the production of energy in cancer cells and stop cancer cells growth for eventually die. ${ }^{38}$ Acetogenin also very selectived, only attacks cancer cells. These compound do not attck other normal cells in the body. ${ }^{38}$ Some derivated, in different type of structures and some isomers showed significant to kill cancer cell line, for example, to fight against prostate cancer. The play mode of action is acetogenin inhibitor of NADH: Oxireductase Uniquinone, the enzyme complex important in oxidative phosphorelation in the mitochondria and inhibits NADH: Oxidase Uniquinone the plasma membrane of the cancer cells. ${ }^{39}$

\section{Conclusion}

The higher the dose of Annona muricata Linn, the higher the p53 expression, thereby activates apoptosis process. Higher dose of Annona muricata Linn also leads to lower hsp70 expression, indicating stable Raji cells homeostasis.

\section{Acknowledgement}

We thank to acknowledge Higher Education Competitive Research Project Ministry of Education and Culture Republic of Indonesia for Grand Featured Research Universities 2013, LPPT of Gajah Mada University. Also, special thanks to Prof. Dr. Ir. Darsono, Prof. Dr. Ari Handoko Ramelan, Prof. Dr. Zainal Arifin Adnan, and Prof. Dr. Rafik Karsidi. Also, special thanks to Prof. Wihaskoro Sosroseno for much inspiration in writing this paper.

\section{Conflict of interest}

The authors declare that they have no conflicts of interest. The authors alone are responsible for the content and writing of the paper.

\section{References}

1. Hildesheim A, West S, DeVeyra E, et al. Herbal medicine use, Epstein-Barr virus, and risk of nasopharyngeal carcinoma. Cancer Res 1992; 52:3048-51. 
2. Astirin O, Artanti A, Fitria M, et al. Annonaa muricata Linn Leaf Induce Apoptosis in Cancer Cause Virus. Journal of Cancer Therapy 2013; 4:1244-50.

3. Yoshizaki T, Ito M, Murono S, et al. Current understanding and management of nasopharyngeal carcinoma. Auris Nasus Larynx 2012; 39: 137-44.

4. Yu MC, Yuan JM. Epidemiology of nasopharyngeal carcinoma. Semin Cancer Biol 2002; 12:421-9.

5. Chang ET, Adami HO. The enigmatic epidemiology of nasopharyngeal carcinoma. Cancer Epidemiol Biomarkers Prev 2006; 15:1765-77.

6. Cao SM, Simons MJ, Qian CN. The prevalence and prevention of nasopharyngeal carcinoma in China. Chin J Cancer 2011; 30:114-9.

7. Smardova J, Pavlova S, Svitakova M, et al. Analysis of P53 Status in Human Cell Line Using a Functional Assay in Yeast: Detection of New no Sense p53 Mutattion in Codon 124. Oncol Rep 2005; 14:901-7.

8. Hicks SD, Lewis L, Ritchie J, et al. Evaluation of cell proliferation, apoptosis, and DNA-repair genes as potential biomarkers for ethanol-induced CNS alterations. BMC Neurosci 2012; 13:128.

9. Adham M, Kurniawan AN, Muhtadi AI, et al. Nasopharyngeal carcinoma in Indonesia: epidemiology, incidence, signs, and symptoms at presentation. Chin J Cancer 2012; 31:185-96.

10. Selye, H. Stress in Health and Disease. Batterworths, Boston and London . Ann Intern Med 1977; 87:799.

11. Vogel EH, Castro ME, Solar PA, Soto FA. Enhancement of Pavlovian conditioned immunosuppression in rats. Acta Neurobiol Exp (Wars) 2007; 67:71-81.

12. Tao Q Chan AT. Nasopharyngeal carcinoma: molecular pathogenesis and therapeutic developments. Expert Rev Mol Med 2007; 9:1-24.

13. Burgos JS. Involvement of the Epstein-Barr virus in the nasopharyngeal carcinoma pathogenesis. Med Oncol 2005; 22:113-21.

14. Cregan SP, MacLaurin JG, Craig CG, et al. Bax-dependent caspase- 3 activation is a key determinant in p53-induced apoptosis in neurons. $\mathrm{J} \mathrm{Neu}$ rosci 1999; 19:7860-9.

15. Bagatell R, Whitesell L. Altered Hsp90 function in cancer: a unique therapeutic opportunity. $\mathrm{Mol} \mathrm{Can-}$ cer Ther 2004; 3:1021-30.

16. Seoane JM, Varela-Centelles PI, Ramirez JR, et al. Heat shock proteins (HSP70 and HSP27) as markers of epithelial dysplasia in oral leukoplakia. Am J Dermatopathol 2006; 28:417-22.

17. Mese H, Sasaki A, Nakayama S, et al. Prognostic significance of heat shock protein 27 (HSP27) in patients with oral squamous cell carcinoma. Oncol Rep 2002; 9:341-4.

18. Macario AJ, Conway de Macario E. Sick chaperones, cellular stress, and disease. $N$ Engl J Med 2005; 353:1489-501.
19. Morishima N. Control of cell fate by Hsp70: more than an evanescent meeting. J Biochem 2005; 137:449-53.

20. Freshney R Ian, Culture of Animal Cells: A manual of Basic Techniques 4th Ed., Wiley-Lies, Canada. 2000.

21. Mursyidi ,Achmad. Statistika Farmasi dan Biologi, Ghalia, Indonesia, Jakarta. 1985.

22. Prayitno A, Asnar E, Astirin O, Putra S. The Expression of CD8+ and MHC-I in Cervical Cancer with HPV Infection. Journal of Cancer Therapy 2013; 4:15-8.

23. Rohman A, Man YB, Riyanto S. Authentication analysis of red fruit (Pandanus Conoideus Lam) oil using FTIR spectroscopy in combination with chemometrics. Phytochem Anal 2011; 22:462-7.

24. Hamizah S, Roslida AH, Fezah O, et al. Chemopreventive potential of Annona muricata $L$ leaves on chemically-induced skin papillomagenesis in mice. Asian Pac J Cancer Prev 2012; 13:2533-9.

25. Shan T, Ma Q Guo K, et al. Xanthones from mangosteen extracts as natural chemopreventive agents: potential anticancer drugs. Curr Mol Med 2011; 11:666-77.

26. Tan W, Lu J, Huang M, et al. Anti-cancer natural products isolated from chinese medicinal herbs. Chin Med 2011; 6:27.

27. Teppo L, Pukkala E, Saxen E. Multiple cancer--an epidemiologic exercise in Finland. J Natl Cancer Inst 1985; 75:207-17.

28. Zhu J, Okumura H, Ohtake S, et al. Arsenic trioxide induces apoptosis in leukemia/lymphoma cell lines via the CD95/CD95L system. Oncol Rep 2003; 10:705-9.

29. Alberts B, Johnson A, Lewis J, et al. Molecular biology of the cell, 4th edition Garland Science, New York 2002.

30. Prayitno A, Darmawan R, Yuliadi I, Mudigdo A.The Expression of p53, Rb dan c-myc proteins in cervical cancer by immunohistochemistry stain. Journal of Biological Diversity 2005; 6.

31. Prayitno A. Cervical cancer with human papilloma virus and Epstein Barr virus positive. J Carcinog 2006; 5:13.

32. Prayitno A, Asnar E, Astirin O, et al. Heat Shock Protein 40 (Hsp40) and Hsp70 Protein Expression in Oral Squamous Cell Carcinoma (OSCC). Journal of Cancer Therapy 2013; 4:734-41.

33. Astirin O.P, Implantasi pada Rattus norvegicus setelah perlakuan dengan Actinomycin D. Thesis, Faculty of Pasca Sarjana, University of Gajah Mada, Yogyakarta, 1991.

34. Macario AJ, Lange M, Ahring BK, Conway de Macario E. Stress genes and proteins in the archaea. Microbiol Mol Biol Rev 1999; 63:923-67. 
35. Horst M, Oppliger W, Rospert S, et al. Sequential action of two Hsp70 complexes during protein import into mitochondria. EMBO J1997;16:1842-9.

36. Neupert W. Protein import into mitochondria. Annu Rev Biochem 1997; 66:863-917.

37. Ryan MT, Naylor DJ, Hoj PB, Clark MS, et al. The role of molecular chaperones in mitochondrial protein import and folding. Int Rev Cytol 1997; 174:127-93.
38. Jiang Z, Chen RY, Chen Y, Yu DQ. Donnaienin, a New Acetogenin Bearing a Hydroxylated Tetrahydrofuran Ring. JNat Prod 1998; 61:86-8.

39. Rieser MJ, Gu ZM, Fang XP, et al. Five novel mono-tetrahydrofuran ring acetogenins from the seeds of Annona muricata. J Nat Prod 1996; 59:100-8. 